\title{
Podostemaceae in Southern Brazil
}

\author{
Podostemaceae na Região Sul do Brasil
}

Anderson Santos de Mello ${ }^{1,3}$, Aldaléa Sprada Tavares ${ }^{2} \&$ Rafael Trevisan ${ }^{2}$

\begin{abstract}
This study provides a taxonomic treatment of the Podostemaceae family in southern Brazil. Podostemaceae is the largest family of strictly aquatic angiosperms. The center of family richness is the equatorial region of South America. Taxonomic studies are still scarce in Brazil. For southern Brazil there are six genera and 10 species recognized. Dichotomous key and illustrations are presented for species identification.

Key words: taxonomy, Malpighiales, aquatic macrophytes, river-weeds.

\section{Resumo}

O presente estudo apresenta um tratamento taxonômico para as Podostemaceae da Região Sul do Brasil. Podostemaceae é a maior família de angiospermas estritamente aquáticas com centro de riqueza na região equatorial da América do Sul. Os estudos taxonômicos ainda são escassos para o Brasil. Para a Região Sul do Brasil são reconhecidos seis gêneros e 10 espécies. São apresentadas chaves dicotômicas e ilustrações para a identificação das espécies.
\end{abstract}

Palavras-chave: taxonomia, Malpighiales, macrófitas aquáticas, plantas de rio.

\section{Introduction}

Podostemaceae is distributed in rivers in tropical regions of the world and some temperate zones of North America and Asia (Tavares 1997), being the largest family of exclusively aquatic Angiosperms, with 50 genera and approximately 270 species (Philbrick \& Novelo 2004). The plants of this family are aquatic herbs, that vary in size, and have unusual morphology for flowering plants. They have simple anatomical features, and generally are very distinct when compared to other groups of aquatic Angiosperms (Ameka et al. 2002). The representatives of this family grow on rocky substrates, in rivers with strong currents. Exceptionally they may occur in lentic ecosystems (Irgang et al. 2003). The life cycle is very singular when compared to other families of Angiosperms, especially because of the need to flower and fruit in synchrony with water-level fluctuations (Tavares et al. 2006). In periods when the rivers have low water levels, some of the plants or even the entire population begins the reproductive process, up to fruit maturity and seed dispersal (Imaichi et al. 2004; Tavares et al. 2006).
Due to their form, sometimes like lichens or bryophytes, the position of Podostemaceae has always been controversial (Tavares 1997) and the phylogenetic relationship discussed (Kita \& Kato 2001). Different classification systems always had difficulty in relating the family to other taxonomic groups. When recognized as a family, it was initially placed among the monocots (Richard 1816; Martius \& Zuccarini 1822). Lindley (1830) was the first to recognize Podostemaceae as a dicotyledonous family. Warming (1888) considered Podostemaceae related to Saxifragaceae. Cronquist (1981) included the family in the monotypical order Podostemales, subclass Rosidae. Cusset \& Cusset (1988), studying the African Podostemaceae, established for the family the exclusive class Podostemopsida. Recently, the classification system APG III (2009) included the family in the order Malpighiales, having as a sister group Hypericaceae and affinities with Clusiaceae and Callophyllaceae. The species with neotropical distribution were recently investigated in a phylogenetical study (Tippery et al. 2011) and the clade clusioid, from the order Malpighiales in which Podostemaceae is included, presented for the first time well resolved phylogeny (Ruhfel et al. 2011).

\footnotetext{
${ }^{1}$ Universidade Federal de Santa Catarina, Programa de Pós-Graduação em Biologia Vegetal, Campus Reitor João David Ferreira Lima, R. Dep. Antonio Edu Vieira, 88040-970, Florianópolis, SC, Brazil.

${ }^{2}$ Universidade Federal de Santa Catarina, Centro de Ciências Biológicas, Depto. Botânica, Campus Reitor João David Ferreira Lima, 88040-970, Florianópolis, SC, Brazil.

${ }^{3}$ Autor para correspondência: japabio@yahoo.com.br
} 
Despite the wide distribution and richness of the species, taxonomic studies of Podostemaceae in Brazil are still scarce, although there have been some important recent contributions (Philbrick \& Bove 2008; Bove et al. 2011). Tulasne (1863), in the Flora brasiliensis, recognized 15 genera and 30 species. Van Royen $(1951,1953,1954)$ did taxonomic treatments for the Americas. The taxonomic decisions of Van Royen represented higher levels of richness and grade of endemism for the South American taxa than those recognized by Philbrick \& Bove (2010). Tavares (1997) studied Podostemaceae from some rivers in the Amazon, associating taxonomy with ecological concepts. Aona \& Amaral (2006) studied the taxonomy of the family for the state of São Paulo. For the state of Santa Catarina Van Royen \& Reitz (1971) indicated the ocurrence of five genera and 13 species. Furthermore, the studies of Pontirolli (1955) and Tur $(1975,1988,1997,1999)$ for Argentina and Paraguay are references for taxonomic studies in southern Brazil, especially because of shared species in the watersheds. New genera and species have being recently described, mainly for Brazil and Argentina (Tur 2003, Philbrick \& Novelo 2003, Philbrick et al. 2005, Philbrick \& Bove 2008). Bove (2010) listed 17 genera and 87 species for Brazil. The scarcity of collections, few field studies, and unrepresentative and poorly preserved exsicatae in the collections favor controversial opinions on the taxonomy of the family (Philbrick \& Novelo 1995). However, some herbaria from southern Brazil have good collections of Podostemaceae, comprising the most of the states of Paraná, Santa Catarina, and Rio Grande do Sul.

This study aims to present a taxonomic treatment of the species of Podostemaceae occurring in southern Brazil.

\section{Material and Methods}

For the taxonomic treatment we followed classical methodology, including a review of the specialized literature, herbarium material, and field expeditions from 2008 to 2010, in which the main rivers of the all important watersheds in southern Brazil were visited. We collected 60 specimens which were included in the collection of the herbarium of Universidade Federal de Santa Catarina, FLOR.

About 300 exsicatae were examined from different herbaria: FLOR, FURB, HAS, HBR, HURG, ICN, LP, MBM, PACA, UPCB, HUCS, from southern
Brazil and CTES and LP, from Argentina (siglas according to Thiers 2010). Part of the type material was not analyzed, because it is deposited in European herbaria; however, images of type material available at the sites of the main herbaria were consulted. The morphological characterization of the vegetative and reproductive structures is according to the terminology used for the family. We accepted the synonymization of Van Royen (1951, 1953, 1954), Tur (1997, 1999), Tavares (1997) and Philbrick \& Novelo 2004.

\section{Results and Discussion}

\section{Taxonomic treatment}

Podostemaceae L.C. Richard ex Kunth. nom. conserv. In: Humboldt \& Bompland - Nova Genera et Species Plantarum. 1: 246-247. 1816.

Aquatic herbs, submerged, fixed to the substrate by haptera, forming or not cenobia. Leaves with variable size and shape, sessile or petiolate, generally with sheath, linear, lanceolate, palmate, reniform, cordate, obovate, reduced to capillary filaments, or thalloid, margin entire or dichotomically subdivided; uninerved, penninerved ou palminerved, surface smooth, papilose or spinulose, phyllotaxy opposite, spiraled, distichous, tristichous, rosulate or fasciculate. Inflorescence a spiciform monochasium, flowers fasciculate or solitary, axillary, basal, terminal, or extra-axillary, conspicuous or tiny, bisexual, zygomorphic or actinomorphic, 1 to many, generally enveloped by a membranous spathella, rare coriaceous, opening irregularly or wrapped by leaves. Perigone (1)35 (many) tepals, sometimes reduced, free, partial or totally fused, triangular, linear, filiform or cordiform. Stamens 1-many, usually alternating with floral segments, free, partial or totally adelphic, forming andropodium or not, filament entire, differently branched, 1 or 2 whorls complete or incomplete, sometimes on one side of the flower, persistent or not; anthers sagittate or rounded, apex emarginate or entire, dehiscence longitudinal, basifixed ou dorsifixed. Ovary superior, gamocarpelar, 1-3 locules, sessile or forming gynophore, ribbed or smooth, pluriovulate, anatropous ovule; stylus 13 , free to slightly fused; stigma entire, retuse or branched. Capsule 1-2 locules, septifragal or septicidal, valves equal or unequal, smooth or ornamented. Seeds 1 to many, ovoid to ellipsoid, exalbuminate; embryo straight. 


\section{Key to the genera of Podostemaceae occurring in southern Brazil}

1. Plants with tristichous phyllotaxy, flowers never surrounded by spathellae; 3 tepals forming a welldeveloped perigone

1. Plants with varied phyllotaxy, never tristichous; flowers always surrounded by spathellae before anthesis; tepals 2 to many, rudimentary, forming whorls complete or not.

2. Flowers arranged in spiciform monochasium; leaves rough due to the presence of papillae on the adaxial surface 3. Mourera

2'. Flowers solitary or in fascicules, never in spiciform monochasium, leaves without papillae.

3. Flowers always solitary, stamens 2 supported by an andropodium ............... 4. Podostemum 3'. Flowers solitary or fasciculate, stamens 1-many, never forming andropodium.

4. Plants acaulescent, phyllotaxy rosulate, nerves conspicuous ................. 2. Marathrum

4'. Plants with developed stem, phyllotaxy alternate, nerves inconspicuous.

5. Leaves pinnate; flowers basal, fasciculate

6. Wettsteiniola

5'. Leaves flabellate or pinnatilobed; flowers axillary or terminal, solitary

1. Apinagia

1. Apinagia Tul., in Ann. Sci. Nat. Bot. ser. 3, 11: 90. 1849.

The literature indicates the occurence of Apinagia yguazuensis, A. guairaensis (Tur, 1999), A. fucoides and A. riedelii (Van Royen 1954, Bove 2010) in southern Brazil. Van Royen \& Reitz (1971) cited A. fucoides for the state of Santa Catarina and suggested the occurrence of $A$. riedelli. However, in the present study only A. yguazuensis was confirmed for southern Brazil.

1.1 Apinagia yguazuensis Chodat et Vischer, Bull. Soc. Bot. Geneve, Ser. 2, 9: 241, 1917.

Figs. 1a-e, 2a-c

Herbs $2-10 \mathrm{~cm}$ tall; roots simple, adhered to the substrate forming a basal disk. Stems erect, $1-10 \mathrm{~cm}$ long. Leaves $1.2-7 \mathrm{~cm}$ long, membranous, decurrent, cuneiform, somewhat flabellate or pinnatilobed, lobes irregular, ending with dichotomous divisions, filiform, inconspicuous, without sheaths. Flowers solitary, axillary or terminal; tepals 3 , rudimentary, subulate, not forming a whorl; stamens 2, inserts on the same side, filaments linear; ovary oblong, slightly asymmetrical, ribs indistinct. Fruit pedunculate, $10 \mathrm{~mm}$ long, bivalve, similar to the ovary, 3 ribs per valve, inconspicuous in young fruit, two lateral sutures.

Selected material: PARANÁ: Braganey, Estância Hermínio e Maria, 1.IV.2000, Borgo et al. 710 (MBM). Céu Azul, Parque Nacional do Iguaçu, 19.III.2004, O.S. Ribas et al. 6106 (MBM). Guaira, Sete Quedas do Rio Paraná, 24.I.1967, G. Hatschbach \& J. Haas 15881 (MBM). 23.IV.1968, G. Hatschbach \& O.V. Guimarães, 19108 (MBM). São José do Oeste, Rio Iguaçú, 7.XII.1968, G. Hatschbach 20537 (MBM). RIO GRANDE DO SUL: Barracão, Rio Marmeleiro, XII.1999, F.A. Silva F. s.n. (ICN 127.606 A), 3.IX.2010, fr., A.S. Mello \& A. Nuernberg 591 (FLOR). SANTA CATARINA: Abelardo Luz, Rio Chapecó, 8.XII.1964, L. Smith \& R.M. Klein 13890 (HBR). 5.IX.2010, fl. e fr., A.S. Mello \& A. Nuernberg 584, 584 a (FLOR). 6.IX.2010, fr., A.S. Mello \& A. Nuernberg 591 (FLOR). Concórdia, Rio Uruguai, 6.XII.1964, Smith \& Klein 13927 (HBR). Additional examined material: ARGENTINA. MISSIONES: Dep. Iguazú, Parque Nacional del Iguazú, camping del Nandu, 11.I.1998, fr., Tur 2138 (LP). 21.II.1998, fr., Tur 2028 (LP). Dep San Ignácio, Salto do Arroyo Tabay, 8.I.1996, fr., Tur 2109 (LP). Foz del Iguazú, 28.IX.1967, H. Fabris \& J. Crisci 7146 (LP).

Apinagia yguazuensis was treated by Van Royen \& Reitz (1971) as A. fucoides in Santa Catarina. However, analysis of specimens from Paraguay and Argentina, associated with new collections from the state, confirmed A. yguazuensis as the taxon occurring in southern Brazil.

The species shows high phenotypic plasticity, varying in size and shape of leaves. Observations on populations occurring in the states of Santa Catarina and Rio Grande do Sul showed that A. yguazuensis lives in streams of low to medium depth and has narrow stems, smaller leaves with yellow to light green coloration. The collection L. Smith \& R. Reitz 13927 (HBR) has wider stems and leaves, terminations dichotomous, filiform and tiny. This morphological variability was also observed by Fontana (2008) within a population.

Apinagia yguazuensis can be considered a rare species in southern Brazil, being proposed as vulnerable (VU) by Philbrick \& Bove (2010), according to IUCN criteria. This species is distributed in the basins of the Paraná, Iguaçu and Uruguay rivers, in the states of Paraná, Santa 


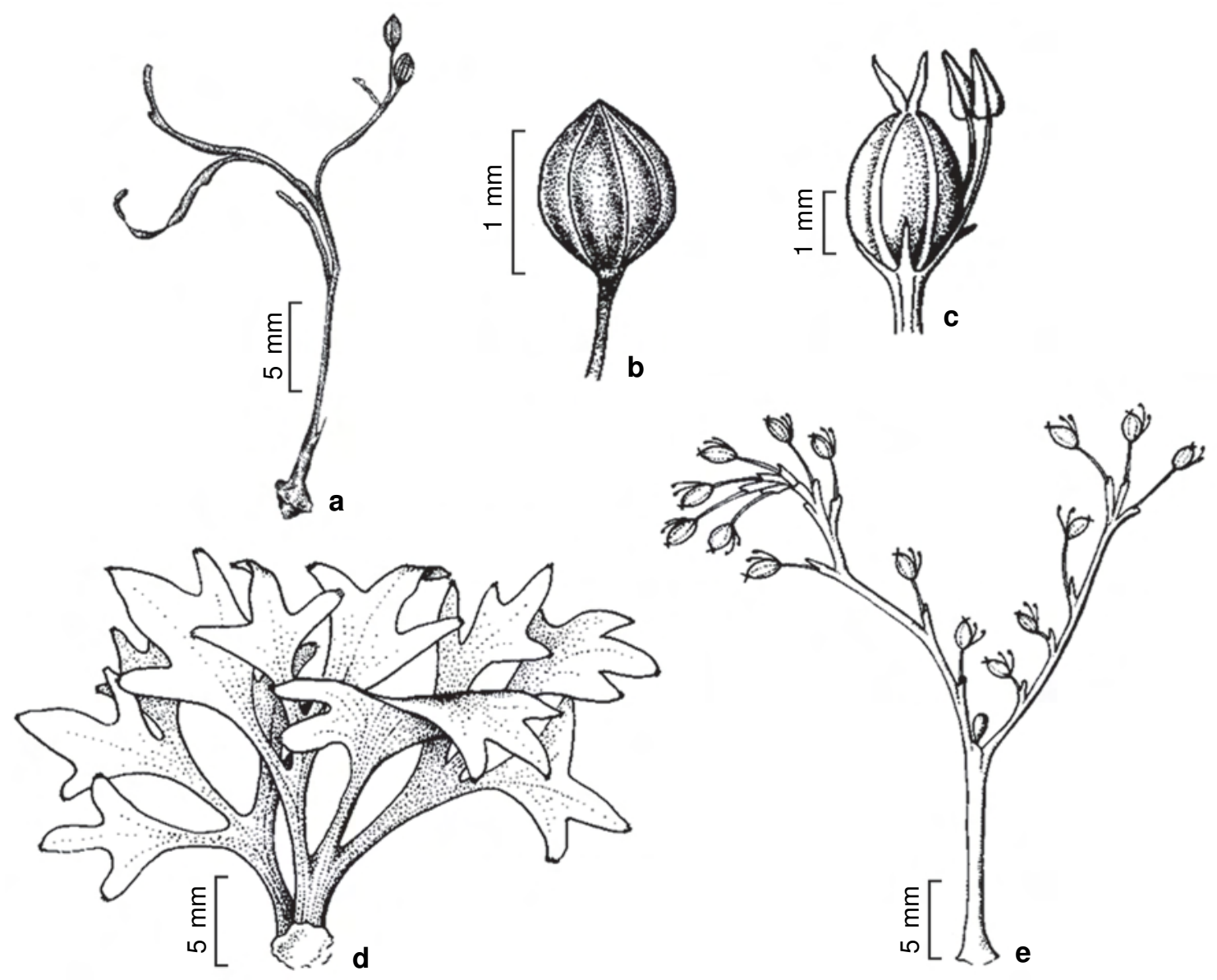

Figure 1 - a-e. Apinagia yguazuensis - a. habit with fruit; $b$. fruit; c. flower; $d$. habit of vegetative specimens; e. fertile specimens. (a-b A.S. Mello \& A. Nuernberg 591; d G. Hatcshbach \& O.V. Guimarães 20237 (MBM); c-e O. Ribas et al. 6106 (MBM)). Illustrations: a-b Maria Virgilia; c-e Fatima Zagonel.

Catarina and Rio Grande do Sul. It also occurs in Paraguay, Paraná River, and in Argentina, in the basins of the Uruguay and Paraná rivers.

2. Marathrum Humb. \& Bonpl., Pl. Aequinoct., 1:39. 1808 .

The genus was previously recognized as restricted to Central America and the Amazon region (Van Royen 1954) and, recently, had its occurrence registered for austral South America with the description of Maratrhum azarensis by Tur (2003).

2.1 Marathrum azarensis Tur, Hickenia 3(38): 153 (151-156; figs. 1-3). 2003.

Fig. 2d-e

Herbs acaulescent, up to $2 \mathrm{~cm}$ tall. Roots thalloid, $1 \mathrm{~mm}$ wide. Leaves opposite or subopposite, rosulate, finely flat, membranous, with conspicuous nerves, cuneate, y pro $2 \mathrm{~cm}$ long, forming laciniae, last leaf divisions 1-2 mm long. Flowers solitary, axillary; spathella when closed forming prominences on the surface before anthesis, broken spathella funnel-shaped, $3 \mathrm{~mm}$ long; tepals 3 , c. $1.5 \mathrm{~mm}$ long, free, apex spatulate; stamens 2, anthers introrse, c. $0.7 \mathrm{~mm}$ long, base emarginate, filaments $1.5-2 \mathrm{~mm}$ long. Ovary ellipsoid, c. $2 \mathrm{~mm}$ long, styli 2, c. $0.5 \mathrm{~mm}$ long. Capsule $2 \mathrm{~mm}$ long, 2 valves equal, persistent, each valve with 3 ribs and 2 longitudinal sutures, pedicels $4 \mathrm{~mm}$ long.

Selected material: SANTA CATARINA: Abelardo Luz, Rio Chapecó, $4 \mathrm{~km}$ ao norte do núcleo urbano, 3.IX.2010, A.S. Mello \& A. Nuernberg 584 (FLOR). Additional examined material: ARGENTINA. MISSIONES: Dep. del Apostoles, Arroyo Chimiray, 25.I.1983, N.M Tur 965 (LP). 7.I.1996, fl., N.M. Tur et al 2104 (Holótipo LP). 

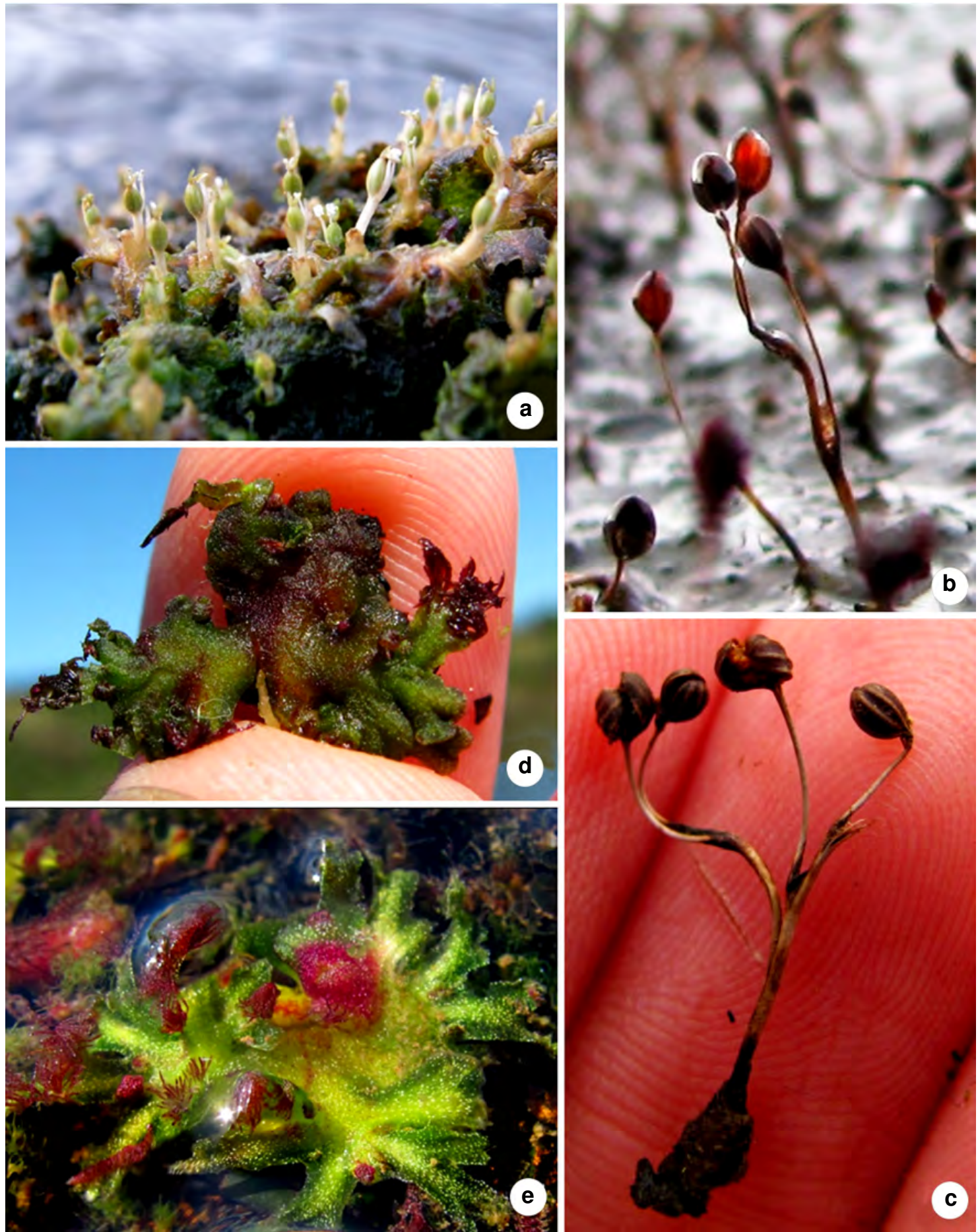

Figure 2 - a-c. Apinagia yguazuensis - a. flowering plants in habitat; b-c. plant with mature fruits. d-e. Marathrum azarensis $-\mathrm{d}$. habit; e. plant in habitat. 
Marathrum azarensis is a new record for Brazil and it is certainly the rarest species of Podostemaceae in southern Brazil. It is considered to be vulnerable (VU) according to IUCN criteria by Philbrick \& Bove (2010).

This species was cited by Bove (2010) for the state of Paraná, although the material referred to by the author had been collected in the Paraná River, in Paraguay, far from the border with Brazil (Fontana 2007). The collection A.S. Mello \& A. Nuernberg 584 (FLOR) in the municipality of Abelardo Luz, Santa Catarina, is in effect the first and only record of the species in Brazil. Marathrum azarensis is hardly recognizable in the field because of its small size and lack of stem. The leaves are flattened, dorsiventral, rosulate, with thick petiole, endings filiform, coloration generally light green and reddish margin.

3. Mourera Aubl., Hist. Pl. Guiana. Fr. 1: 582. 1775. For the genus Mourera we registered the occurrence of $M$. aspera Tul., restricted to the state of Paraná. Mourera weddelliana Tul. was cited for Santa Catarina (Van Royen \& Reitz 1971), however it was not confirmed, and the only reference is an undated collection by Müller s.n., which can not be analyzed.

3.1 Mourera aspera (Bong.) Tul. Ann.Sci. Nat. Bot. ser.3, 11: 93. 1849.

Fig. $3 \mathrm{a}-\mathrm{d}$

Herbs, variable size. Leaves $5.5-35 \mathrm{~cm} \times 3-15$ $\mathrm{cm}$, adaxial surface rough, nerves prominent on the adaxial face, with remarkable papillae, abaxial face glabrous. Monochasium spiciform, simple ou branched, 4-23 cm long; rachis 5.5-17.5 cm long; bracts c. $5 \mathrm{~mm} \times 2 \mathrm{~mm}$, in the inflorescence branches. Flowers numerous; spathella 5-8 mm; pedicel 1-2 cm long; tepals 5-10, 5-9 mm long; anthers extrorse, obtuse or emarginate, basifixed, 2-3 mm. Capsule 3.5-4.5 mm long, 8-10 ribbed; pedicel up to $3.5 \mathrm{~cm}$ long in ripe fruit.

Selected material: PARANÁ: Capitão Leônidas Marques, Rio Iguaçú, 21.III.1993, Silva s.n. (UPCB 23990). Foz do Rio Cotegipe, 17.IV.2004, P.H. Labiak et al. 3218 (MBM, UPCB). Foz do Iguaçú, Parque Nacional do Iguaçú, 3.X.2006, fl., P.H. Labiack 3803 (UPCB). 24.I.1967, fl., G. Hatschbach 15869 (MBM). Guaira, Sete Quedas do Rio Paraná, 23.VII.1967, Y.S. Kunyoshi 4288 (MBM). 23.IV.1968, fl., G. Hatschbach \& O.V. Guimarães 19106 (HBR, MBM 38666). 10.VI.1980, $R$. Butura s.n. (MBM).

Additional examined material: ARGENTINA. CORRIENTES: Dep. del Ytuizaingó, 30.VIII.1994, S.
Umana 1 (LP). Dep. Iguazú, Parque Nacional del Iguazú, 9.I.1996, N.M. Tur 2124 (LP). 11.I.1996, N.M. Tur 2137 (LP). M.Herrera 83 (LP). MISSIONES: Dep. Iguazú, Parque Nacional del Iguazú, Cataratas del Iguazú, 19.IV.1951, A. Cabrera et al. 185 (LP). 21.XI.1992, N.M. Tur 2036 (LP).

Mourera aspera was collected in southern Brazil in only a few areas in northwestern Paraná. This species has a very restricted area of distribution, so far, only in the basins of the Paraná and Iguaçú rivers. Although Van Royen \& Reitz (1971) presented a taxonomic treatment and indicated its possible occurrence in the state of Santa Catarina, there are no herbarium records or field observations that confirm the occurrence of the species in that state. Mourera aspera has the largest leaves and flowers of the southern Podostemaceae. The most striking morphological features are the size and shape of leaves, inflorescence a spiciform monochasium, pink flowers, and the rough papillae that cover the adaxial surface of leaves, composed of a set of siliceous cells.

In southern Brazil, the species was collected in rivers of the watershed of the Paraná River, in the western portion of the state. In addition to Paraná, this species occurs in the states of Bahia, Espírito Santo, Goiás, Mato Grosso, Minas Gerais, São Paulo, and Rio de Janeiro. It is also found in Argentina and Paraguay.

4. Podostemum Mich., Fl. Boreal. Am. 2: 164. 1803. Podostemum is the genus with the most species in southern Brazil, including five species. The most striking feature of the genus is the presence of an andropodium, a structure that bears the base of two stamens with anthers. Despite all available literature and the species of the genus being the most common and well reprepresented in collections in austral South America, the taxonomy is still controversial. The monograph on Podostemum (Philbrick \& Novelo 2004) used phylogenetic analysis based only on morphological characters and presented a new proposal for the treatments of Van Royen (1954), Van Royen \& Reitz (1971) and Tur (1988, 1997, 1999). According to Van Royen (1954), the genus has 12 species in south Brazil and Van Royen \& Reitz (1971) cited the occurrence of seven species in Santa Catarina. In contrast, Philbrick \& Novelo (2004) justified that the species recognized by Van Royen (1954) are, in fact, local forms of species with greater distribution. Those authors recognized only four species (Podostemum comatum Hicken, P. distichum (Cham.) Wedd., P. muelleri Warm. and P. rutifolium Warm.) and added $P$. irgangii Philbrick \& Novelo. 
This study was innovative, but it led to a discussion concerning their taxonomic conclusions, requiring intensification of taxonomic studies. The genus Crenias Spreng, treated by Van Royen \& Reitz (1971) as Mniopsis Mart, had no confirmed occurrence for southern Brazil. In addition, the species of Crenias were transferred to Podostemum by Philbrik \& Novelo (2004), a situation with which we do not agree.

\section{Key to the species of Podostemum occuring in southern Brazil}

1. Leaves usually entire, base of the leaves broad, asymmetrical, with extensions filiform simple or dichotomous; stipules entire, with a basal triangular tooth, visible only on one face of the leaves.....

4. P. muelleri

1'. Leaves compound, base of the leaves narrow, symmetric, often dichotomized or composed by leaflets in spiral arrangment; stipules consisting of two or more teeth, with variable morphology, visible on both faces of the leaves.

2. Plants with dimorphic stems; vegetative up to $115 \mathrm{~cm}$ long, fertile $0.1-2 \mathrm{~cm}$ long .... 1. P. comatum

2' Plants with monomorphic stems, not differentiating the vegetative from the reproductive.

3. Stipules of two kinds, the first composed of two ear lobes, symmetrical, arising one on each side of the stem, the second composed of a set of 3-9 teeth subequal, inserted above the petiole 3. P. irgangii

3'. Stipule of only one kind, with 2-7 teeth, the lateral asymmetric.

4. Divisions of the leaves in the same plane, endings of the leaves spatulate or rarely acute; stipules always with two equal teeth 5. P. rutifolium

4. Divisions of the leaves tridimensional, endings of the leaves varied; stipules with 2-7 teeth of different sizes and shapes

2. P. distichum

1. Podostemum comatum Hicken., Rev. Chilena Hist. nat., 21(6):149.1917. Figs. $4 \mathrm{a}-\mathrm{d}, 5 \mathrm{a}$

Herbs of variable size. Roots $0.8-2 \mathrm{~mm}$ wide. Stem dimorphic, twisted, little branched, $2-115 \mathrm{~cm}$ long when vegetative and $1.5-2 \mathrm{~cm}$ long when reproductive. Leaves $2-20 \mathrm{~cm}$ long, dichotomously divided, divisions appearing in two dimensions; apex of endings elongate, rounded to acute; petiole flattened; stipules amplexicaulis, with 2(-3) triangular teeth, 0.2$1.5 \mathrm{~mm}$ long. Flowers growing on short stalks arising from the roots; pedicel $0.5-1.5 \mathrm{~cm}$; tepals 3 , linear to filiform, andropodium 1-3 mm long; ovary ellipsoid, 1-2.7 mm long; stigmas entire, filiform, $1-1.5 \mathrm{~mm}$. Capsule $2 \mathrm{~mm}$ long, 2 valves unequal, 3(-5) ribs on each valve.

Selected material: PARANÁ: Telêmaco Borba, Ponte sobre o rio Santa Rosa, 14.XI.2009, A.S. Mello \& M. Beretta 553 (ICN). Tomazina, Rio das Cinzas, 17.VIII.2007, fr., J.M. Silva et al. 6038 (MBM). RIO GRANDE DO SUL: Cachoeira do Sul, Passo do Cortado, 3.IX.1979, fl., J.L. Waechter \& L. Baptista 1353 (ICN, HAS). Derrubadas, Parque Estadual do Turvo, 1980, J.L. Waechter 1654 (ICN, CTES). Dom Pedrito, I.1998, C.T. Philbrick et al. 5030 (ICN). Pinheiro Machado, $31^{\circ} 13.266$ S, $54^{\circ} 16.731$ O, I.1998, C.T. Philbrick et al. 5028 (ICN). Vila Lageado Grande, Rio Lageado Grande, I.1998, C.T. Philbrick et al. 5267 (ICN).
Additional examined material: ARGENTINA. MISSIONES: Dep. del Apostoles, Arroyo Chimiray $10 \mathrm{~km}$ al sur de Azara, 25.I.1983, N.M. Tur 567 (LP). Dep. Iguazú. Parque Nacional del Iguazú, s.d., A.L. Cabrera et al. 58 (CTES). CORRIENTES: Dep. Ituzaingó, Salto Apipé, 28.X.1982, s.c. s.n. (LP). PARAGUAY. AMABAY: Cerro Corá, Rio Aquidabán Nigui, 17.VIII.1980, A. Schinini \& E. Bordas 20242 (CTES, MBM). ALTO PARANÁ: Caballero, C. Marmori 2049 (CTES). URUGUAY. Dep. del Artigas, Arroyo Sepulturas, C. Bonifácio et al. 1935 (CTES).

Podostemum comatum is rare in southern Brazil, despite its wide dispersion area in the three states. The herbarium collections are limited and usually incomplete, especially the dimorphic stems, often collected separately and treated as distinct species. During field work it was not possible to collect this species in Santa Catarina, requiring intensified new sampling. In the municipality of Telêmaco Borba, Paraná, a population was found with stems over one meter in length, a fact never reported before in the literature.

Podostemum comatum is distributed in the states of Paraná, Santa Catarina and Rio Grande do Sul. It also occurs in the state of São Paulo and in Argentina, Paraguay and Uruguay. 


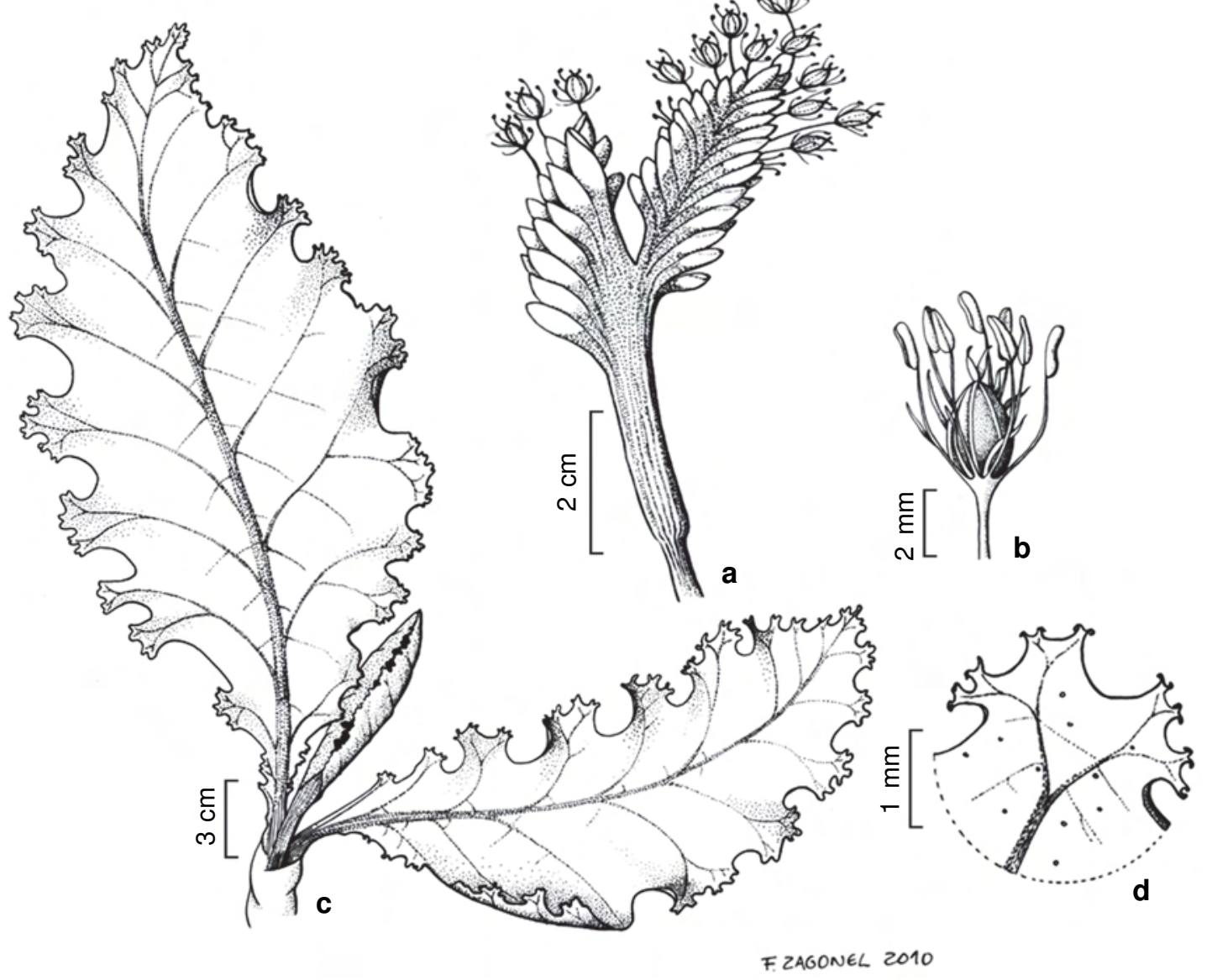

Figure 3 - a-d. Mourera aspera - a. inflorescence; b. flower; c. stem with leaves; d. papillae at the tip of the leaves. (G. Hatschbach 42235 (MBM)). Illustrations: Fatima Zagonel.

2. Podostemum distichum (Cham.) Wedd. Prodromus. 17: 73. 1873.

Figs. 5b-d, 6a-c

Herbs. Roots prostrate, flattened, $0.6-2.9 \mathrm{~mm}$ wide. Monomorphic stems, older rigid, dark and twisted, 0.4-600 $\mathrm{mm}$ long. Leaves peciolate, compound, inserted perpendicularly on the stem axis, distichous, variable forms, when verticillate, 2 or 3 axes from which arise leaflets; when dichotomous, 2-8 dichotomic divisions emerging in three dimensions, last divisions of leaves in $\mathrm{V}$ or $\mathrm{U}$ shape, apex acute, $0.2-15 \mathrm{~cm}$ long; stipules emerging as an extension of the sheath navicular-shaped, persistent, hard and darkened in older stems, $0.2-1.4 \mathrm{~mm}$ long, 2-7 teeth of different sizes, triangular, lateral larger than the central, $0.05-0.3 \mathrm{~mm}$ long. Flowers $1-5$ per stem; tepals 3, 2 lateral and 1 at the bifurcation of the andropodium; andropodium $0.3-5.2 \mathrm{~mm}$ long; ovary reddish, 6-8 ribs, stigmas entire. Capsule bivalvar, 3-4 ribs per valve.
Selected material: PARANÁ: Céu Azul, Cachoeira do Rio Azul, 26.VI.2007, F. Barbosa et al. 2181 (MBM). General Carneiro, Rio Nene, 7.III.2006, A.C. Cervi et al. 8877(UPCB). Guaira, Sete Quedas do Rio Paraná, 6.XII.1968, G. Hatschbach \& O.V. Guimarães 20526 (MBM). Ponta Grossa, Cachoeira da Mariquinha, 6.II.2008, J.M. Silva et al. 6342 (MBM). Salto Morato, Cachoeira Salto Morato, 12.I.1991, G. Hatschbach \& J.M. Silva 56124 (MBM). Tibagi, Rio do Engenho Velho, 14.XI.2009, A.S. Mello \& M. Beretta 555 (FLOR). RIO GRANDE DO SUL: Bom Jesus, 16.I.1942, B. Rambo 9027,(PACA). Canela, Passo do Inferno, 10.II.1941, S.J. Rambo 4827 (PACA). Caxias do Sul, Vila Seca, S.J. Rambo 54828 (HBR, PACA). Espumoso, Rio Butiá, 28 50.171'S, 5242.667'O, C.T. Philbrick et al. 50705074 (ICN). Jaquirana, Cascata dos Venâncio, Estrada de Cambará para Jaquirana, corredeiras, s.d., V.F. Kinnupp 2892 (ICN). Lavras do Sul, Fazenda do Posto, 17.X.1971, J.C. Lindeman \& B. Irgang s.n. (ICN 8663). Maquiné, 29³0.472S, 50¹4.556O, 25.I.1998, C.T. Philbricket al. 5187-5188(ICN). Montenegro, Linha Campestre, 2.X.1950, fr., A. Sehnem 4946 (HUCS, PACA). Osório, Cerro do Umbú, 31.XII.1934, fr., 


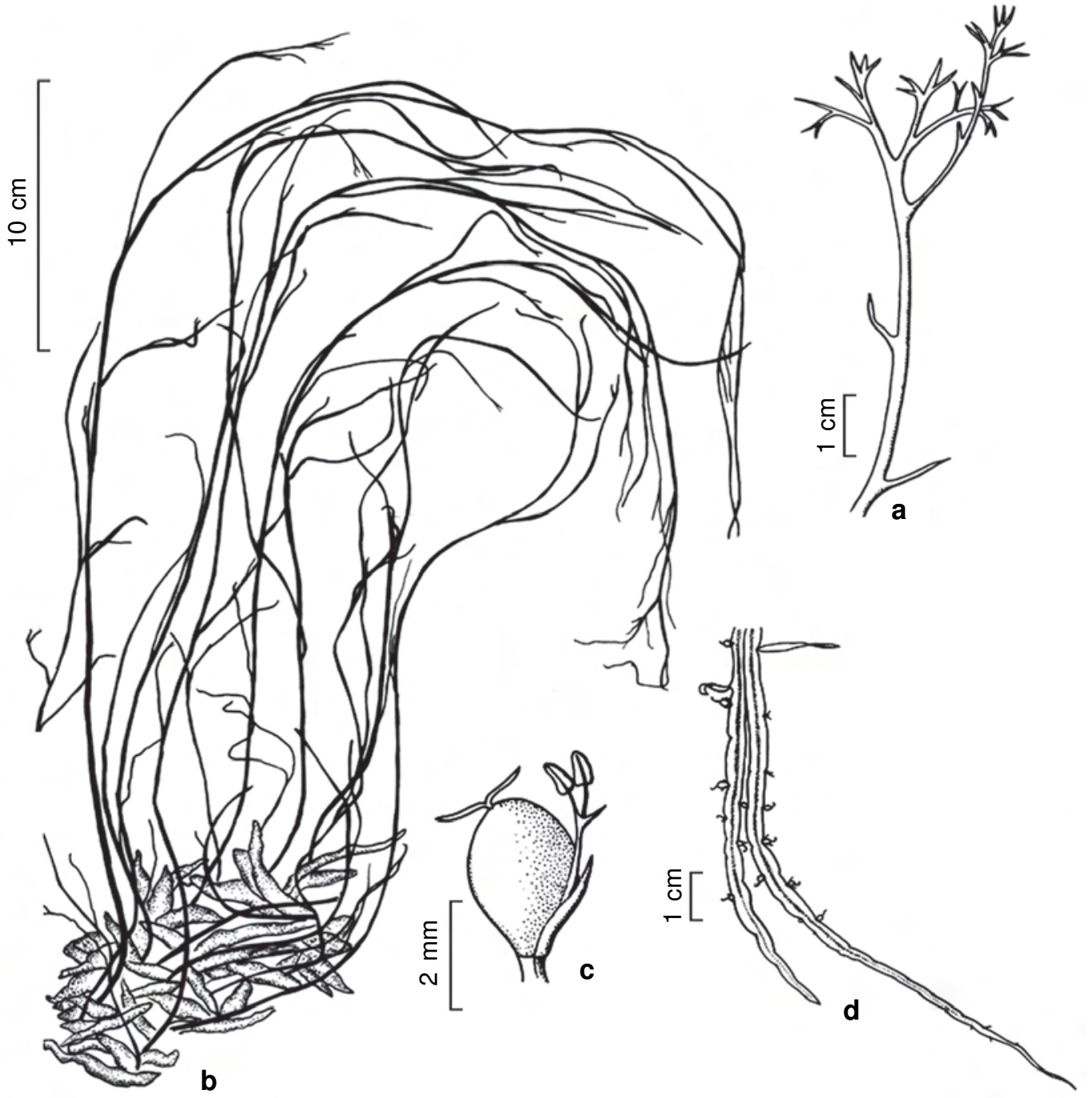

Figure 4 - a-d. Podostemum comatum - a. terminal portion of the stem; b. roots with fertile stems; c. flower; d. roots with vegetative stems. (a A.S. Mello \& M. Beretta 553 (FLOR); b-d Silva et al.6036,6038 (MBM)). Illustrations: a-c Fatima Zagonel; d Maria Virgilia.

S.J Rambo 1258 (PACA). Santa Cruz do Sul, Rio Francisco Alves, 5.XII.1991, fl. e fr., J.L. Waechter 2508 (ICN, HAS). São Francisco de Paula, Rio Gueira, 10.II.1941, S.J. Rambo 4748 (PACA). Soledade, $28^{\circ} 36.846 \mathrm{~S}, 52^{\circ} 36.592 \mathrm{O}$, I.1998, C.T. Philbrick et al. 5055 (ICN). Vacaria, Fazenda da Ronda, 8.I.1947, S.J. Rambo 34957 (HBR, PACA). Vale do Sol, 29॰40.798S, 52³0.416O, C.T. Philbrick et al. 5003-5007 (ICN). Vale Vêneto, 7.III.1956, fl., A. Sehnem 1339(PACA). SANTA CATARINA: Abelardo Luz, 5.IX.2010, est, A.S. Mello \& A. Nuernberg 582, $582 a$ (FLOR). 5.IX.2010, A.S. Mello \& A. Nuernberg 587 (FLOR). Bom Jardim da Serra, 13.I.1965, L. Smith \& R. Reitz 14189(HBR). Campos Novos, 12.IX.1963, R. Reitz \& R.M. Klein 16177 (HBR). Corupá,
Cascata 5, 17.III.2009, A.S. Mello 557 (FLOR). Herval do Oeste, Rio Irani, 3.IX.2010, fl., A.S. Mello \& A. Nuernberg 578, 578a, 578b, 578c (FLOR). Lajes, A. Krapovichas \& A. Schinini 38352 (CTES). Lauro Muller, Rio do Oratório, 20.II.1959, R. Reitz \& R.M. Klein 8491 (HBR). Passos Maia, Ponte Baixa, 4.IX.2010, fl., A.S. Mello \& A. Nuernberg 581, 581a, $581 b$ (FLOR). Rio do Sul, Alto Matador, 30.XII.1958, R. Reitz \& R.M. Klein 6110 (HBR). São José do Cerrito, Passo dos Fernandes, 3.IV.2009, fl., A.S. Mello \& A. Nuernberg 573 (FLOR). São Joaquim, 12 km da cidade de São Joaquim, 6.I.1965, fr., L. Smith \& R. Reitz 14333 (HBR). Urubici, $28^{\circ} 08^{\circ} 43000 \mathrm{~S}, 49^{\circ} 37^{\prime} 06.000 \mathrm{O}, 9$. V.2009, A.L. Gasper 2089 (FURB). 

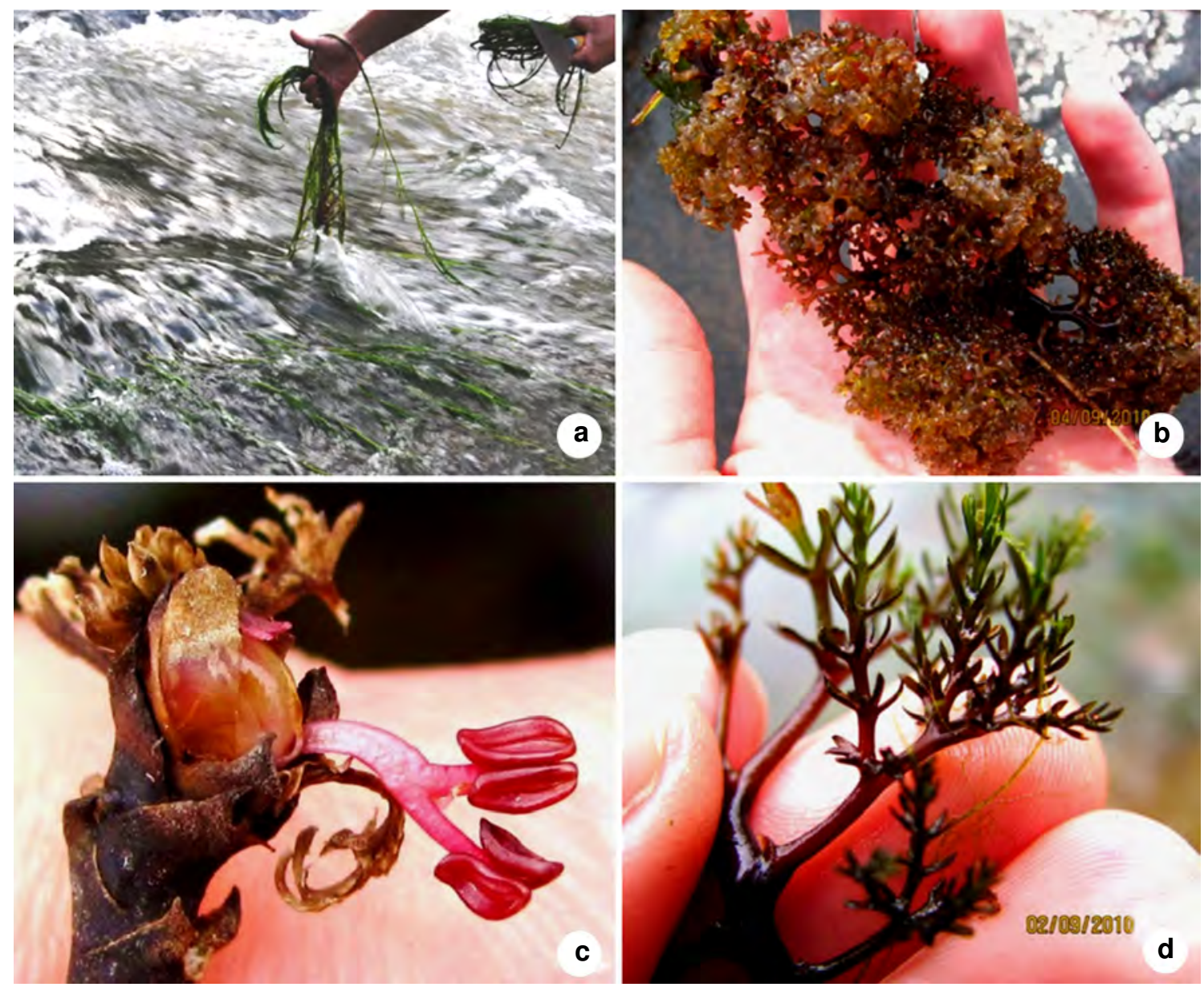

Figure 5 - a. Podostemum comatum - population with stems up to $115 \mathrm{~cm}$ long. b-d. Podostemum distichum - b. stems with short leaves; c. flower with recently split spathella; d. leaves with verticillate leaflets.

Additional examined material: ARGENTINA. ENTRE RIOS: Dep. Concordia, Salto Grande, 10.II.1967, N.M. Tur 955 (LP). MISIONES: Dep. Cainguás, Salto las Golandrinas, 18.X.1975, F.O. Zuloaga 559 (LP). PARAGUAY. CONCEPCIÓN: Rio Ypané, $6 \mathrm{Km}$ de Belen, 30.IX.1985, R. Wolf s.n. (LP).

Podostemum distichum is the most common species, with the greatest dispersion area in southern Brazil, occurring preferentially in waterways on the South Brazilian Plateau, forming dense communities with $P$. comatum, $P$. muelleri, $P$. rutifolium and Tristicha trifaria. In field works we realized that it is common at higher altitudes. $P$. distichum has the highest morphological variability within the genus, with little- or much-divided leaves, verticillate or not and stems short or long. It differs from other species by the leaf divisions arising in three dimensions.
Philbrick \& Novelo (2004) synonymized $P$. atrichum, $P$. arguirense, $P$. glaziovianum, $P$. schenckii and $P$. warmingii under $P$. distichum. However, the phylogenetic approach of Moline et al. (2006), including morphological and molecular characters, indicated that the proposed complex should be carefully studied. The analysis of collections and field work were crucial to note this complexity. Although we are accepting the proposal made by Moline et al. (2006), it is necessary to intensify work and it will probably be given new taxonomic positions.

In Brazil, Podostemum distichum is widely distributed over the three southern states, as well as São Paulo and Minas Gerais. It also occurs in Argentina, in the basins of the Uruguay River and Paraná rivers, in Paraguay and Uruguay. 

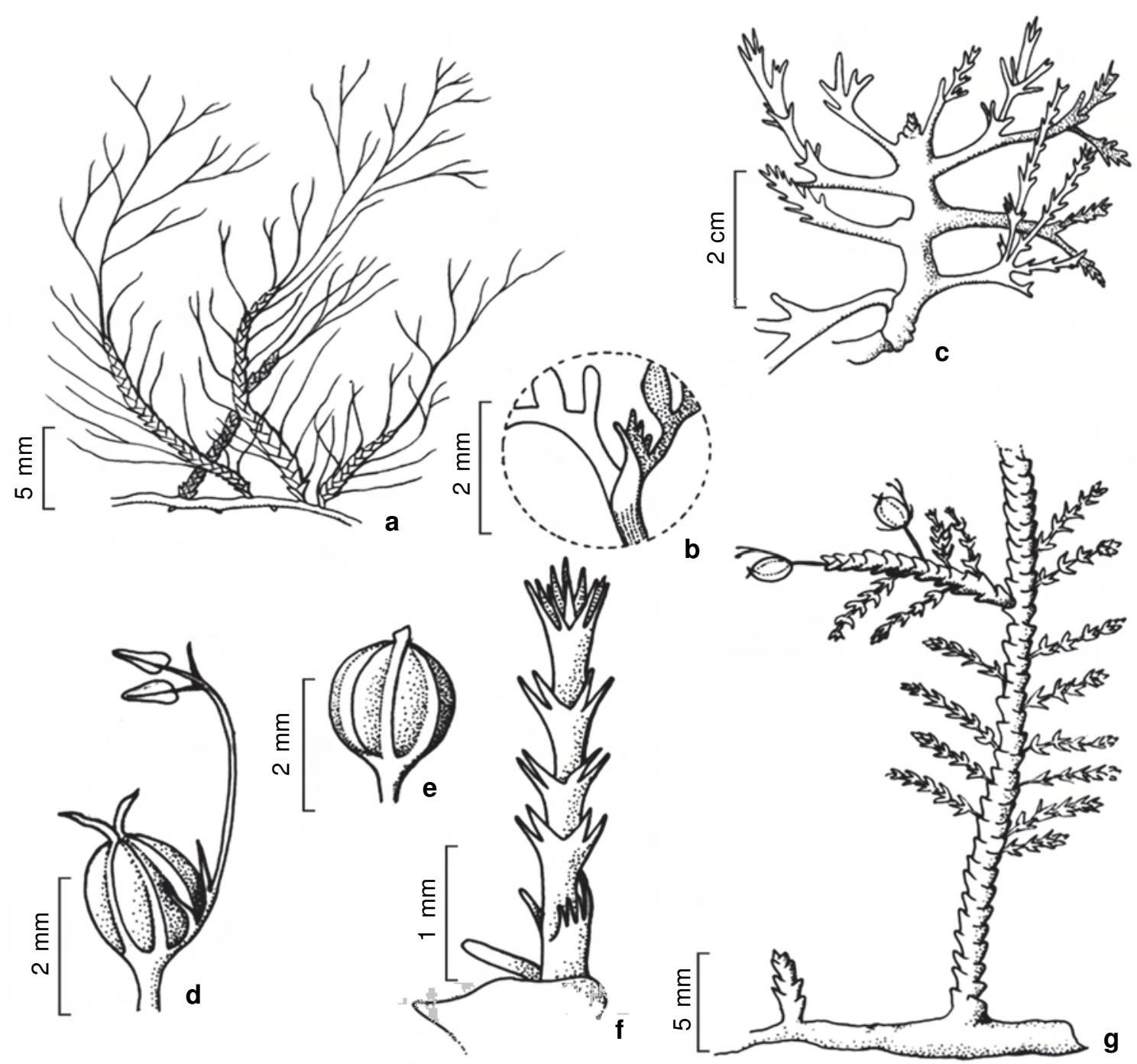

Figure 6 - a-c. Podostemum distichum - a. roots with stems and leaves; b. stipule detail; c. stems with leaves and verticillate leaflets. d-g. Podostemum irgangii - d. flower; e. fruit; f. leaf; g. roots with stems, leaves and flowers. (a-c A.S. Mello \& A. Nuernberg 581 (FLOR); d-g A.S.Mello \& A. Nuernberg 587 (FLOR)).Illustrations: Fatima Zagonel

3. Podostemum irgangii C. T. Philbrick \& A. Novelo, Novon 11: 92. 2001. Figs. 6d-g, 7a-b

Herbs. Roots prostrate, rounded, $0.2-2.1 \mathrm{~mm}$ wide. Monomorphic stems, prostrate or erect, $1-42 \mathrm{~mm}$ long. Leaves distichous, divided, divisions of the leaves verticillate, $1-5 \mathrm{~cm}$ long; whorls uniformly arranged, 5-14 whorls per leaf, 6-11 leaflets per whorl, 3.1$7.2 \mathrm{~mm}$ long, apex acute. Petioles $0.2-0.4 \mathrm{~mm}$ long; base symmetric, perpendicular to the axis of the stem, hard; stipules in two forms, hard, symmetric, persistent, dark in older stems; first type located at the base of the leaf insertion on the stem, with two lobes, $0.7-1.1 \mathrm{~mm}$ long, subamplexicaulis, protruding
0.4-0.6 $\mathrm{mm}$ from the stem; second type appearing above the insertion of the petiole; teeth 4-9, $0.2-0.5 \mathrm{~mm}$ long. Flowers $1-7$ per stem, solitary; tepals 3 , linear, sometimes curved, 2 lateral, 0.6-2mm long and 1 at the bifurcation of the andropodium, $0.4-1.5 \mathrm{~mm}$ long; andropodium $0.3-1.7 \mathrm{~mm} \times$ c. $4.5 \mathrm{~mm}$. Ovary $0.8-$ $2.1 \mathrm{~mm} \times 0.8-1.6 \mathrm{~mm}$; stigmas 2, entire, $0.4-1.6 \mathrm{~mm}$. Capsule 1.2-2.2 $\times 0.9-1.7 \mathrm{~mm}$; peduncle $1-6 \mathrm{~mm}$ long. Selected material: PARANÁ: Clevelândia, Rio Chopim, 1.V.1966, fl., J.C. Lindeman \& J. Haas 1151 (HBR). Laranjeiras do Sul, Rio Canto do Galo, 26.IV.1968, fr., $G$. Hatschbach 19182 (MBM). RIO GRANDE DO SUL: Barracão, Rio Marmeleiro, 3.IX.2010, fl. e fr., A.S. Mello 

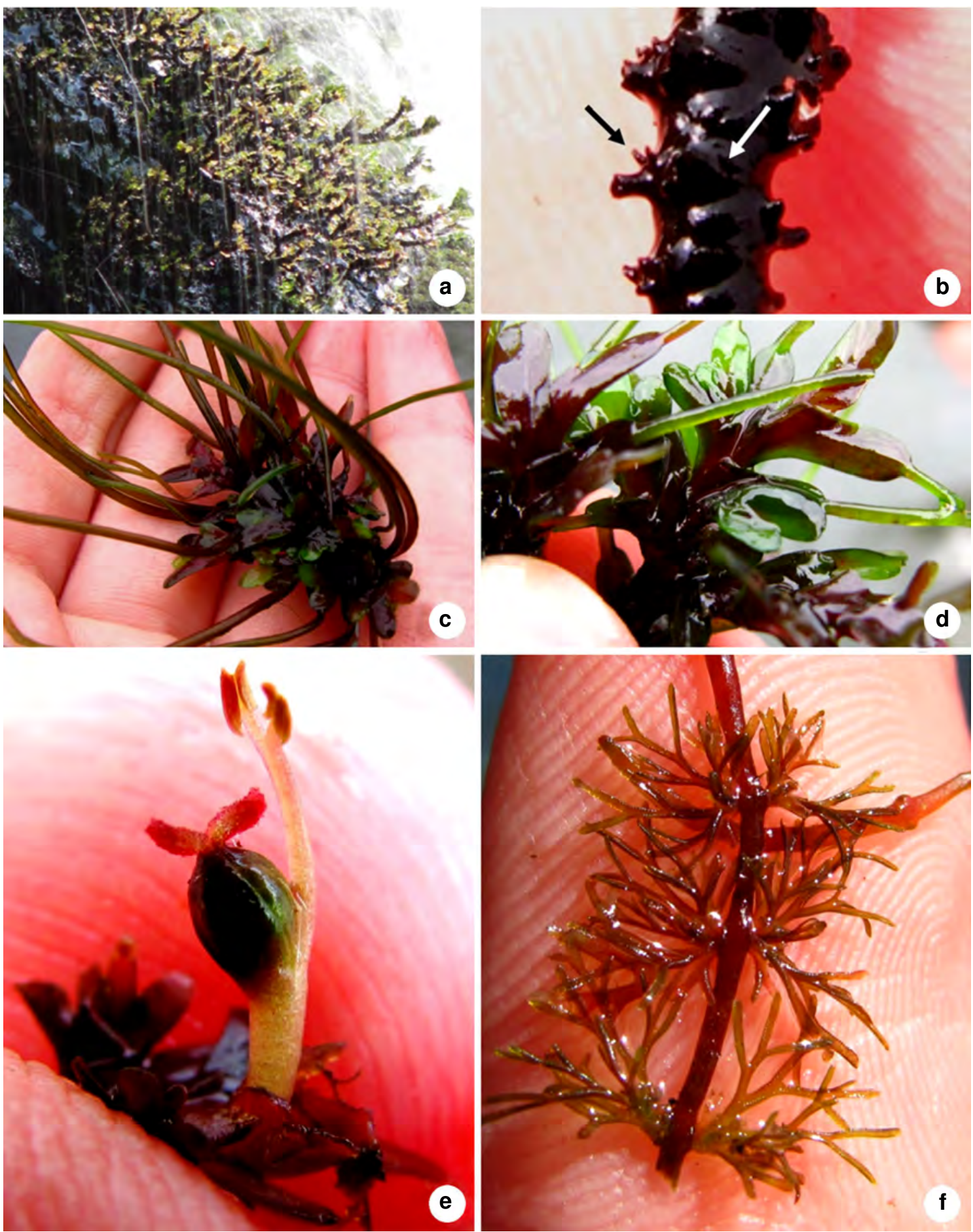

Figure 7 -a-b. Podostemum irgangii - a. population in the habit; b. two kinds of stipules, left arrow line corresponds to leaf stipule, right arrow line corresponds to stem stipule. c-e Podostemum muelleri - c. stem with leaves; d. leaves with characteristics broad-base; e. flower. f. Podostemum rutifolium - roots, stems and leaves. 
\& A. Nuernberg 592 (FLOR). SANTA CATARINA: Abelardo Luz, Quedas do Rio Chapecó, 5.IX.2010, A.S. Mello \& A. Nuernberg 586 (FLOR). Prainha, 5.IX.2010, fl., e fr., A.S. Mello \& A. Nuernberg 583 (FLOR). Anita Garibaldi, Passo do Rio Canoas, 21.XII.1962, R. Reitz \& R.M. Klein 14432 (HBR). Campo Erê, Rio Capetinga, 26.XII.1956, fl., L. Smith \& R. Reitz 9290 (HBR). Campos Novos, Ibicuí, 9.VII.1963, R. Reitz \& R.M. Klein 15097 (HBR). Herval do Oeste, Rio Irani, 3.IX.2010, fl., e fr., A.S. Mello \& A. Nuernberg 577 (FLOR). Joaçaba, Rio Irani, 3.I.1957, L. Smith \& R. Reitz 9888 (HBR). Passos Maia, Ponta Baixa, 3.IV.2010, fl. e fr., A.S. Mello \& A. Nuernberg $580 b$ (FLOR). São José do Cerrito, Passo dos Fernandes, 3.IV.2009, fl., A.S. Mello \& A. Nuernberg 574 (FLOR).

Podostemum irgangii is the unique species of the genus with two kinds of stipules. Another striking feature is the even distribution of the verticillate whorls. However, identification of Podostemum irgangii and $P$. distichum may be grossly mistaken. $P$. irgangii has two forms of stipules and its leaves are usually evenly verticillate. Moreover, in communities where both species occur together, Podostemum irgangii usually has stems and leaves darker and harder. Among the criteria used for diagnosis of the species, stipules and uniform verticillate division of the leaflets were not present in all populations analyzed. Some populations have one or more divisions of the leaves in which the leaflets are inserted irregularly. Likewise, some individuals had smooth stems and the stipules were inserted only above the petiole. Although some populations of Podostemum irgangii are easily identified, the morphological variability found, mainly in rivers when associated with Podostemum distichum, indicates the need for increasing collections. Podostemum irgangii is the only species of the genus endemic to southern Brazil. It was considered to be vulnerable (VU) by Philbrick \& Bove (2010). In the present study it is recorded for the first time in Rio Grande do Sul. It occurs only in rivers located in the western portion of the Araucaria Plateau, which compound the basins of the Iguaçú and Uruguay rivers. Due to the large loss of habitats and the small area of distribution, the species is in serious danger of extinction.

4. Podostemum müelleri Warm. Kongel. Danske Vidensk. Selsk. Skr., Naturvidensk. Math. Afd. ser. 6, 4: 445, 480 (t. 16-17). 1888 Warm. Fam. Podostem. 3: 1, 38, pl. 16, 17. 1888. Figs. 7c-e

Herbs. Roots prostrate, $0.3-8 \mathrm{~mm}$ wide. Monomorphic stems. Leaves usually sessile, simple, entire or with 1-4 divisions dichotomic, $0.1-$ $34 \mathrm{~mm} \times 0.2-1.5 \mathrm{~mm}$; blades linear to spatulate, divisions dichotomic emerging in two dimensions; base of the leaves flattened, asymmetric, wider than the blade, obliquely inserted on the stem, flexible or hard; stipule simple, asymmetric, forming a visible tooth only on one side, entire or slightly emaginate flattened, persistent and hardened in older stems. Flowers 1-10 per stem; tepals 3, 2 latera $0.5-1.9 \mathrm{~mm}$ long and 1 at the bifurcation of the andropodium 0.1-1.3 mm long; andropodium 0.1-3 mm long; ovary $0.8-2.3 \times 0.6-1.8 \mathrm{~mm}, 6-8$ ribs; stigmas entire. Capsule 1-2.7 mm $\times 0.9-1.9 \mathrm{~mm}$; 68 ribs, 3-4 per valve.

Selected material: PARANÁ: Candói, Rio Jordão, $G$. Trepolo \& S.R. Tiller 281 (MBM). Céu Azul, Parque Nacional do Iguaçú, 19.III.2004, fl., O.S. Ribas et al. 6133 (MBM). Foz do Iguaçú, Cataratas do Iguaçú, 17.IV.1964, G. Hatschbach 11219 (MBM). Prudentópolis, Rio dos Patos, 27.XII.1972, G. Hatschbach 31061 (MBM). RIO GRANDE DO SUL: Bom Jesus, Rio das Antas, I.1998, C.T. Philbrick et al. 5146-5148 (ICN). Cambará do Sul, 22.I.1998, C.T. Philbrick et al. 5120-5130 (ICN). Ijuí, Rio Conceição, I.1998, C.T. Philbrick et al. 5050-5052 (ICN). Maquiné, Rio Forqueta, 25.I.1998, C.T. Philbrick et al. 5189-5191 (ICN). Riozinho, Cascata do Arroio Conduto, 26.I.1998, C.T. Philbrick et al. 5208 (ICN). Santa Maria, Rio Vacacaí, I.1998, C.T. Philbrick et al. 5010 (ICN). São Francisco de Paula, I.1998, C.T. Philbrick et al. 5200 (ICN). SANTA CATARINA: Abelardo Luz, Quedas do Rio Chapecó, 5.IX.2010, est, A.S. Mello \& A. Nuernberg 589 (FLOR). Anitápolis, Rio da Prata, VII.2010, est, A.S. Mello 569 (FLOR). Blumenau, Rio Tafona, I.1998, C.T. Philbrick et al. 5181, 5182 (ICN). Caçador, Rio Castelhanos, 9.I.1962, fr., R. Reitz \& R.M. Klein 11874 (HBR). Herval do Oeste, Rio Jacutinga, 3.IX.2010, A.S. Mello \& A. Nuernberg 576 (FLOR). Herval do Oeste, Rio Irani, 3.IX.2010, fl. e fr., A.S. Mello \& A. Nuernberg 579 (FLOR). Itapiranga, Rio Uruguai, 31.I.1957, S.J. Rambo 60293 (PACA, HBR). São José do Cerrito, 3.IV.2009, A.S. Mello \& A. Nuernberg 574 (FLOR).

Additional examined material: ARGENTINA. CORRIENTES: Dep. San Tome, Estancia Garruchos, Arroyo Garabi, 10.X.1969, Pedersen 9236 (MBM). ENTRE RIOS: Concordia, Salto Grande, 10.II.1967, Tur 954 (LP). MISIONES: Dep Eldorado, Arroyo Aguará Mimí, 22.II.1070, Tur 1309 (LP). Dep. Guarani, Beira do Arroyo Yaboti, 8.V.1999, N. Deginari 1145 (LP). Dep. Montecarlo, Arroio Salto Anita, W. Keller 125 (CTES).

Podostemum müelleri is recognized by the enlarged base of the leaves and the stipules consisting of a tooth and only visible on one side. Podostemum müelleri presents wide distribution in the southern states of Brazil, as wel as São Paulo and Goiás. It also occurs in Argentina, Paraguay and Uruguay. 


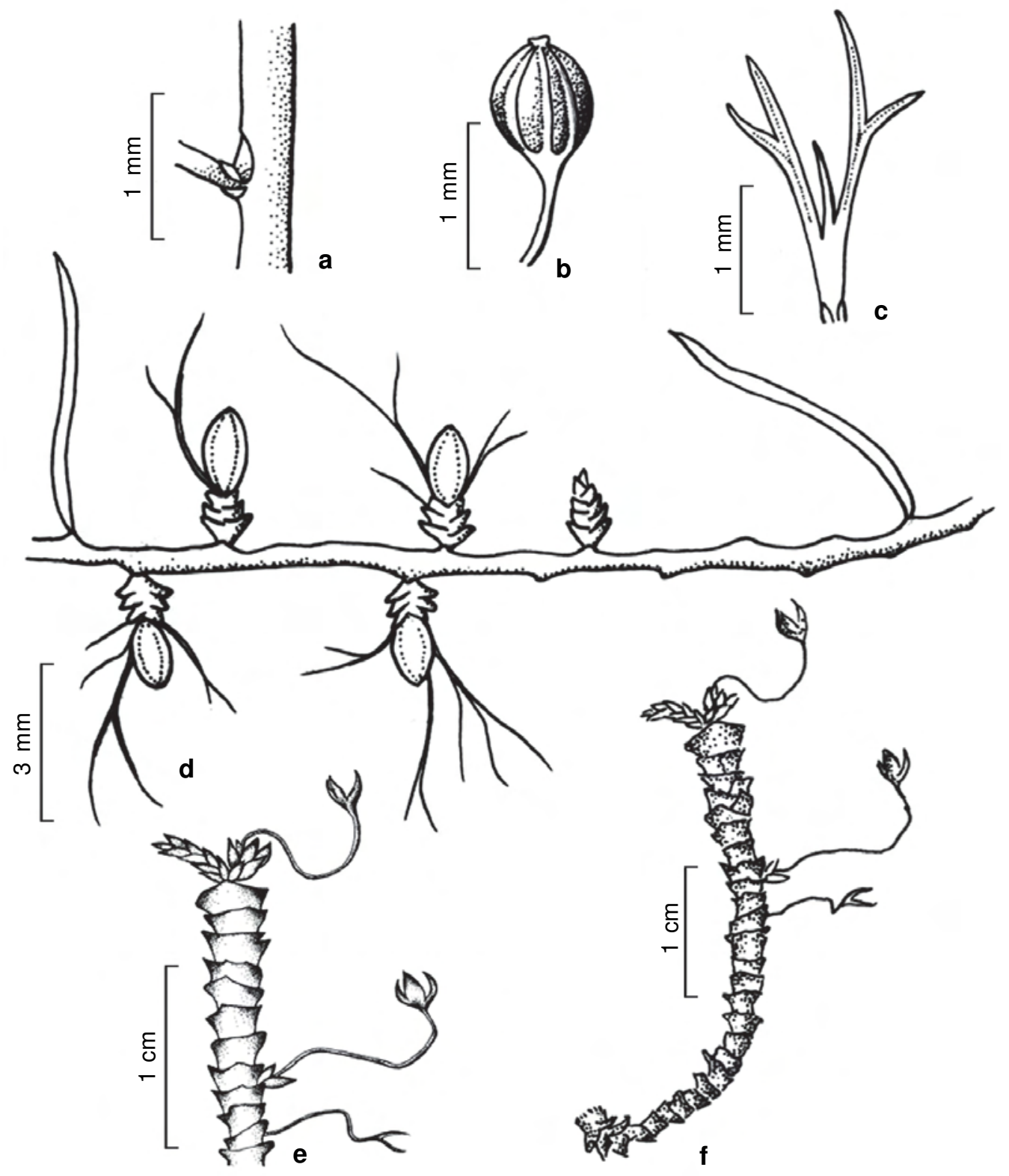

Figure 8 - a-d. Podostemum rutifolium - a. leaf with stipules; b. fruit; c. leaf; d. roots with stems, leaves and closed spathellae. e-f. Tristicha trifaria - e. stem with flowers; f. terminal portion of the stem with flowers. (a-d A.S. Mello 4, (FLOR); T.B. Guimarães 345 (FLOR)).

5. Podostemum rutifolium Warm. Vidensk. Selsk. Skr, ser 6, 9 (2): 127, 1899.

Figs. 7f, 8a-d

Herbs. Roots prostrate, flattened, $0.2-3.4 \mathrm{~mm}$ wide. Monomorphic stems, small, 0.1-94 mm long. Leaves distichous, entire to 5 times dichotomized or lobed, 1.5-20 mm long, spatulate; apex rounded, obtuse or acute, $0.9-2.1 \mathrm{~mm}$ long; base of the leaves symmetric; stipules $0.01-0.4 \mathrm{~mm}$ long, persistent, hardened and darkened in older stems, 2 teeth triangular and flattened, $0.05 \mathrm{~mm}$ long. Flowers 1-5 per stem; tepals 3, apex acute, 2 lateral $0.6-1.7 \mathrm{~mm}$ long and 1 at the bifurcation of the andropodium 0.2-1.2 long; ovary reddish pink, 810 ribs, $0.4-2.1 \times 0.4-1.5 \mathrm{~mm}$; stigmas entire. Capsule $1.2-2.3 \mathrm{~mm} \times 0.8-1.6 \mathrm{~mm}$; $8-10$ ribs, $4-5$ per valve. 
Selected material: PARANÁ: Capitão Leônidas Marques, Rio Iguaçu, 7.IV.2004, P.H. Labiack et al. 3219 (MBM). Guaira, Sete-quedas do Rio Paraná, 24.I.1967, G. Hatschbach \& Haas 15868 (MBM). RIO GRANDE DO SUL: Bom Jesus, Rio Moraes, 22.I.1998, C.T. Philbrick et al. 5134, 5135, 5140, 5141, 5144, 5145 (ICN). Herval, I.1998, C.T. Philbrick et al. 5025, 5026 (ICN). Lajeado, Arroio Forquetinha, 19.I.1998, C.T. Philbrick et al. 5091-5094 (ICN). Santa Cruz do Sul, Passo do Rio Pardo, 29.XI.1976, J.L. Waechter 227 (HAS). São Lourenço do Sul, Laguna dos Patos, XII.1998, Philbrick et al. 5021 (ICN). SANTA CATARINA: Abelardo Luz, Prainha, 5.IX.2010, fl. e fr., A.S. Mello \& A. Nuernberg 588 (FLOR). Corupá, Rio Bruaca, 17.III.2009, fr., A.S. Mello 5 (FLOR). Dionísio Cerqueira, Rio Peperi-guaçu, XI.1956, L. Smith 9675 (HBR). Ibirama, Rio Itajaí do Norte, 13.XI.1956, L. Smith et al. 7589 (HBR). Pouso Redondo, $27^{\circ} 17.650 \mathrm{~S}, 50^{\circ} 02.5990$, II.1998, C.T. Philbrick et al. 5160-5162, 5169-5176 (ICN). São José do Cerrito, Passo dos Fernandes, 3.IV.2009, fl., A.S. Mello \& A. Nuernberg 572 (FLOR).

Additional examined material: ARGENTINA. ENTRE RIOS: Concordia, Salto grande, 21.IX.1951, A. Cabrera 10854B (LP). Federación, Rio Uruguay, 19.XII.1974, J.J. Neiff s.n. (LP). MISSIONES: Dep. Eldorado, Arroyo Piray Guazu, 21.II.1070, N.M. Tur 1318 (LP). Dep. Guarani, Arroyo Yaboti $27^{\circ} 08^{\prime} \mathrm{S}$, 5359W, A. Deginian 1143 (LP). PARAGUAY. AMAMBAY: Parque Nacional del Cerro Cora, 22 39'S, 5003O, 20.II.1982, est, J.C. Solomon 7141 (LP).

Podostemum rutifolium is recognized by very small leaves, blade spatulate, apex obtuse, rarely acute. The stems usually are diminute, inserted in opposite way along the roots. The stems and leaves are prostrate. In areas where it is dominant, it forms dense populations. Philbrick \& Novelo (2004) propose two subspecies for $P$. rutifolium: $P$. rutifolium subsp. rutifolium, occurring in austral South America and P. rutifolium subsp. ricciforme to Central America. Both subspecies are differentiated only by leaf size and disjunct occurrence. In the present study we do not consider any of the subspecies, since leaf size is not a significant character in the circumscription of taxa in this family.

Podostemum rutifolium is common in southern Brazil, mainly in rivers in the states of Rio Grande do Sul and Santa Catarina. It also occurs in Argentina, Paraguay, and Uruguay.

5. Tristicha Thouars Gen. Nov. Madagascar.: 3. 1806.

The genus belongs to the subfamily Tristichoideae, recognized by Engler (1930) and considered by many authors as a different family, because it is characterized by the absence of spathella before anthesis and by having whorls that involve all floral parts. Recent works on the biogeography of Tristicha (Kita $\&$ Kato 2004) suggested that this genus had originated in Africa and dispersed to other continents, following a reverse path of the other species of the family.

5.1 Tristicha trifaria (Bory ex Willd.) Spreng., Syst. Veg., ed. 16: 1-22. 1824 Fig. 8e-f

Herbs with branching roots, adhered to the substrate. Branches prostrate, attached or floating, $0.2-15 \mathrm{~cm}$ long. Leaves with phyllotaxy tristichous, laxly or densely arranged along the stem, membranous, sessile, entire, rarely lobed. Flowers axillary or terminal, solitary or not, surrounded by membranous leaves; tepals 3, connate at the base; stamen 1; anthers oblong, base obtuse, apex truncated, dehiscence introrse; ovary sessile, ovoid to ellipsoid, tricarpelar, trilocular; stigmas 3. Capsule similar to the ovary, trivalvar dehiscent; seeds minute, numerous.

Selected material: PARANÁ: Capitão Leônidas Marques, Rio Iguaçú, 7.IV.2004, fr., P.H. Labiack et al. 3220 (MBM). Cerro Azul, Rio Ponta Grossa, 13.XI.2009, A.S. Mello \& M. Beretta 551 (FLOR). Céu Azul, Parque Nacional do Iguaçú, 19/III/2004, O.S. Ribas et al. 7451 (MBM). Guaira, Sete Quedas, 23.IV.1968, fr., G. Hatschbach 19130 (MBM). RIO GRANDE DO SUL: Candelária, Passo do Rio Pardo para Candelária, 29.II.1976, J.L. Waechter 225 (ICN). Derrubadas, Salto Yucumã, 1981, P. Brack s.n. (ICN). Quaraí, Rio Quaraímirim, 21.XI.1973, A. Girardi \& B. Irgangi s.n. (ICN). Riozinho, $29^{\circ} 29.194 \mathrm{~S}, 50^{\circ} 26.5800$, XII.1997, C.T. Philbrick et al. 5207 (ICN). SANTA CATARINA: Biguaçú, Rio da Prata, 22.III.2010, A.S. Mello \& A. Nuernberg 578 (FLOR). Blumenau, 26 ${ }^{\circ} 52.426 \mathrm{~S}$, 49¹3.830O, I.1998, C.T. Philbrick et al. 5183 (ICN). Caçador, Rio Timbó, hidrelétrica do Rio Timbó, 22.XII.1956, fr., Smith \& Reitz 9047 (HBR). Concórdia, Rio Uruguai, 9.I.1957, fl., Smith \& Reitz 9913 (HBR). Passos Maia, Ponte Baixa, 4.IX.2010, est, A.S. Mello \& A. Nuernberg $580 b 1$ (FLOR).

Additional examined material: ARGENTINA. MISSIONES: Dep. Iguazú, Parque Nacional del Iguazú, abajo del Salto Bosseti, 10.I.1996, Tur 2127 (LP). Dep. San Javier, Florentino Ameghino, Arroyo 11 vueltas, paso Kalesplaner, 3.II.1995, Tur 2080 (LP). MEXICO. GUERRERO: Ometepec, Tlacochistlahuaca, 7.XII.1994, s.c. s.n. (LP).

Tristicha trifaria has received little attention from collectors, possibly due the diminute size and the appearance that resembles a bryophyte. Herbarium colletions are very often mixed mainly with 

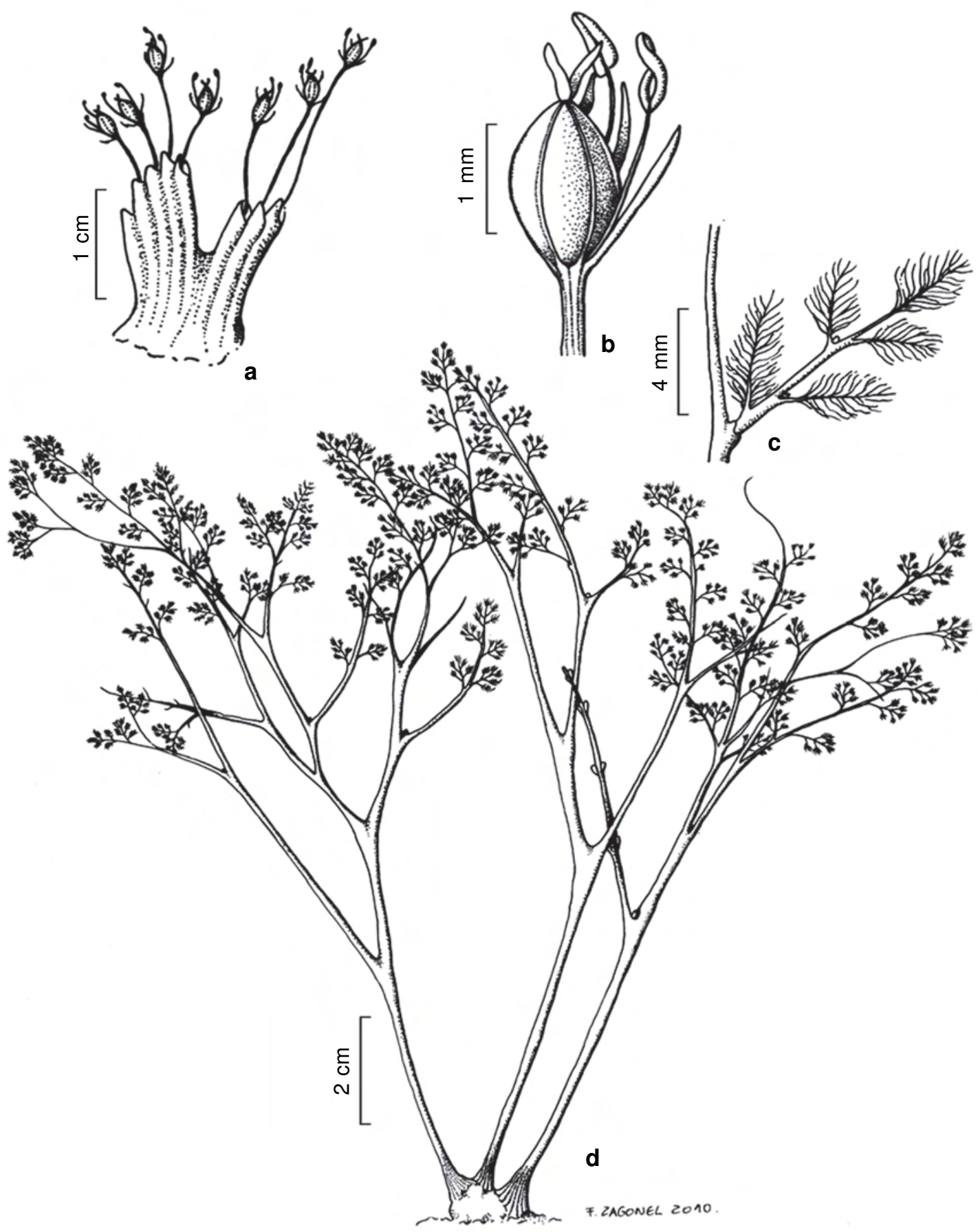

Figure 9 - a-d. Wettsteiniola pinnata - a. flowers emerging in fascicle; b. flower; c. leaf; d. habit. (a-d Hatschbach 42236, 15871 (MBM)). Illustration: Fatima Zagonel. 
specimens of Podostemum. This species is easily recognized in the fertile condition by large pedicels and three tepals involving the ovary. The tristichous phyllotaxy also assists in the identification.

Tristicha trifaria is widely distributed in southern Brazil, occurring mainly in communities with species of Podostemum. The species is the only one in the family that has a Pantropical distribution, occurring also in Africa. However, biogeographic analyses (Kita \& Kato 2004) indicate that there are possibly two different species, one confined to the African continent and the other to the Americas.

\section{Wettsteiniola Suess., Repert. Spec. Nov. Regni} Veg. 39:18. 1935

The genus is endemic to the basin of the Paraná River and composed by W. apipensis, W. accorsii and $W$. pinnata, the first two are known only from the type locality. Wettsteiniola apipensis occurs only in the Salto Apipe, Corrientes province, Argentina. Wettsteiniola accosii occurred in the former Salto de Piracicaba, in the municipality of Piracicaba, state of São Paulo. In southern Brazil, only W. pinnata, occurs in the state of Paraná. The genus presents affinities with species of the section Hymenolacys of the genus Apinagia, especially by arranging clusters of flowers at the thalloid base, forming fascicles.

6.1 Wettsteiniola pinnata Süess., Repert. Spec. Nov. Regni Veg. 39: 18. 1935.

Fig. 9a-d

Base or root thalloid, irregular, peltate, 5-10 $\mathrm{mm}$ diam. Leaves bipinnate, $8-10 \mathrm{~cm}$ long, petiole 4-5 cm long, 3-5mm diam., rachis flattened.; first division of the sheet up to $1.5 \mathrm{~cm}$ long, secondary divisions repeatedly furcated, last divisions numerous, filiform, 2-4 cm long, stipules up to $3 \mathrm{~mm}$ wide. Flowers in fascicules, arising from the thalloid base; pedicels up to $3.5 \mathrm{~cm}$ long; tepals $3-5$, membranous, apex acute, up to $0.5 \mathrm{~mm}$ long; stamens $1-4$, up to $3 \mathrm{~mm}$ long, anthers up to $1 \mathrm{~mm}$ long. Ovary c. $3 \mathrm{~mm}$ long, $2 \mathrm{~mm}$ diam; styli acute. Capsule, bivalvar, c. 2 mm long, with 12 to 14 ribs, 6 to 7 per valve.

Selected material: BRAZIL. PARANÁ: Guaira, Sete Quedas do Rio Paraná, 24.I.1967, G. Hatschbach \& Haas 15871 (MBM). Tomazina, Rio das Cinzas, Salto Cavalcanti, 17.VIII.2007, fl.e fr., J.M. Silva et al. 6037 (MBM).

Wettsteiniola pinnata has the type indicated for the Paranapanema River, Salto Grande, São Paulo, Brazil. In addition to the type, we found specimens from the extinct "Sete-quedas" of the Paraná River, municipality of Guaira and the collections Silva et al.
6034 and 6037 (MBM) from Salto Cavalcanti, Rio das Cinzas, municipality of Tomazina, northwestern Paraná. Unfortunately, the field work in Salto Cavalcanti took place during periods of heavy rainfall, so the expedition was unsuccessful. The Salto Cavalcanti is a large waterfall with high flow, which drains into the basin of the Paraná River. The only collections for the genus Wettsteiniola were conducted in rivers with large waterfalls, located in the Paraná River basin.

Wettsteiniola pinnata has a very restricted distribution, occurring in southern Brazil only in the state of Paraná. The type of the species is indicated for the state of São Paulo, in Rio Paranapanema, however this river is located on the border with the state of Paraná and new collections of the species were not done in São Paulo. In addition, a revision of the genus may include $W$. pinnata and W. accorsii as synonyms.

\section{Acknowledgements}

The authors thank the herbaria curators for the loan the exsicatae; the Programa de PósGraduação em Biologia Vegetal of UFSC; Fátima Zagonel and Maria Virgília for the illustrations; Anelise Nuernberg and Mariane Beretta for photographs and CAPES for the scholarship granted to the first author.

\section{References}

Ameka, G.K.; Pfeifer E. \& Rutishauser, R. 2002. Developmental morphology of Saxicolella amicorum and S. submersa (Podostemaceae: Podostemoideae) from Ghana. Botanical Journal of the Linnean Society 139: 255-273.

Aona, L.Y.S. \& Amaral, M.C. 2006. Podostemaceae. In: Wanderley, M.G.L.; Shepherd G.J.; Melhem, T.S. \& Giulietti. (orgs.). Flora fanerogêmica do estado de São Paulo. Vol. V. Edusp, São Paulo. Pp. 237-258.

APG III. 2009. An update of the Angiosperm Phylogeny Group classification for the orders and families of flowering plants: APG III. Botanical Journal of the Linnean Society 161: 105-121.

Brummit, R.K. \& Powell, C.E. 1992. Authors of plant names. Royal Botanic Gardens, Kew.

Bove, C.P. 2010. Podostemaceae In: Lista de espécies da flora do Brasil. Jardim Botânico do Rio de Janeiro. Disponível em <http://floradobrasil.jbrj.gov.br/2010/ FB000194>. Acesso em 21 Out 2010.

Bove, C.P.; Philbrick, C.T. \& Costa, J.E.M. 2011. Taxonomy, distribution and emended description of the Neotropical genus Lophogyne (Podostemaceae). Brittonia, 63: 156-160. 
Cronquist, A. 1981. An integrated system of classification of flowering plants. Columbia University Press, New York. 1262p.

Cusset, C. \& Cusset, G. 1988. Etudes sur les Podostemopsida repartition et evolution des Tristichaceae. Bulletin Museum d'Historie Natural Paris. Ser. 4 (10); Sec. B., Adansonia 3: 223-262.

Engler, A. 1930. Podostemaceae. Die Naturlichen Pflanzenfamilien. 2. 18a: 1-68. figs. 1-61.

Fontana, J.L. 2007. Marathrum (Podostemaceae), un nuevo gênero para el Paraguay. Candollea 62: 146-148.

Fontana, J.L. 2008. Aspectos ecológicos y nuevas citas de Apinagia yguazuensis (Podostemaceae). Boletín Sociedad Argentina de Botánica 43: 269-272.

Hicken, C.M. 1917. Podostemaceas Argentinas. Revista Chilena de Historia Natural 21: 148-151.

Holmgren, P.K.; Holmgren, N.H. \& Barnett, L.C. 1990. Index Herbariorum. Part I: The herbaria of the world. 8th ed. New York Botanical Garden, New York. 693p.

Imaichi, R.; Maeda, R.; Suzuki, K. \& Kato, M. 2004. Developmental morphology of foliose shoots and seedlings of Dalzellia zeylanica (Podostemaceae) with special reference to their meristems. Botanical Journal of the Linnean Society 144: 289-302

Irgang, B.I.; Senna Gastal Jr., C.T.; Philbrick, A. \& Novelo, R. 2003. A ocorrência inédita de uma Podostemaceae nas costas de uma laguna (Laguna dos Patos) no Rio Grande do Sul, Brasil. Caderno de Pesquisa Série Biologia, Santa Cruz do Sul 15: 7-12.

Kita,Y. \& Kato, M. 2001. Infrafamilial phylogeny of the aquatic angiosperm Podostemaceae inferred from the nucleotide sequences of the matK Gene. Plant Biology 3: 156-163.

Kita, Y. \& Kato, M. 2004. Phylogenetic relationships between disjunctly occurring groups of Tristicha trifaria (Podostemaceae). Journal of Biogeography 31: 1605-1612.

Lindley, J. 1830. An introduction to natural system of botany. Pp. 175-176.

Martius , H.F. \& Zuccarini, J.G. 1822. Nova genera et species plantarum. 1: 6 .

Mathew, C.J.; Nileena, C.B. \& Jäger-Zürn., I. 2003. Morphology and ecology of two new species of Polypleurum (Podostemaceae) from Kerala, India. Plant Systematic. Evolution 237: 209-217.

Michaux, A. 1803. Flora boreali Americana. Systems caracteris plantarum. 2 vols. Typis Caroli Crapelet. Parisiis \& Argentoraté. 164p. tab.44.

Moline, P.M.; Philbrick, C.T.; Novelo, A.; Pfeifer, E. \& Rutishauer, R. 2006. Comparative morphology and molecular systematicas of Podostemum (including Crenias) - American river-weeds (Podostemaceae). Botanische Jahrbücher für Systematik,
Pflanzengeschichte und Pflanzengeographie. Vol. 126. Leipzig. Pp. 427-476.

Philbrick, C.T. \& Novelo, R.A. 1995. New world Podostemaceae: ecological and evolutionary enigmas. Brittonia 47: 210-222.

Philbrick, C.T. \& Novelo, A. 2003. A new species of Podostemum (Podostemaceae) from the states of Paraná and Santa Catarina, Brazil. Novon 11: 92-96.

Philbrick, C.T. \& Novelo, A. 2004. Monograph of Podostemum (Podostemaceae). Systematic Botany Monogrphs 70: 1-72.

Philbrick, C.T.; Novelo, A.R. \& Irgang, B.E. 2005. Two new genera of Podostemaceae from the state of Minas Gerais, Brazil. Systematic Botany 29: 109-117.

Philbrick, C.T. \& Bove C. 2008. A new species of Castelnavia (Podostemaceae) from Tocantins, Brazil. Novon 18: 94-98.

Philbrick, C.T. \& Bove, C. 2010. Endemism in neotropical Podostemaceae. Annals of the Missouri Botanical Garden 97: 425-456.

Pontiroli, A. 1955. Podostemáceas Argentinas. Boletim Sociedad Argentina. Botánica 6: 1-20.

Richard, L.C. 1816. In: Humboldt \& Bonpland. Nova genera et species plantarum. Libraire greqcqueLaténe-Allemande 1: 246-247.

Rufhel, B.R.; Bittrich, V.; Bove, C.P.; Gustafsson, M.H.G.; Philbrick, C.T.; Rutishauser, R.; Xi, Z. \& Davis, C.C. 2011. Phylogeny of clusoid clade (Malpighiales): Evidence from the plastids and mitochondrial genomes. American Journal of Botany 98: 306-325.

Tavares, A.S. 1997. Podostemaceae de alguns rios de água preta do estado Amazonas. Tese de Doutorado. Instituto Nacional de Pesquisas da Amazônia, Universidade do Amazonas, Manaus.

Tavares, A.S.; Odnetz, O. \& Enricone, A. 2006. A família Podostemaceae em rios amazônicos e comunidades de insetos associados. Insula 35: 19-50.

Thiers, B. 2010 [continuously updated]. Index Herbariorum: a global directory of public herbaria and associated staff. New York Botanical Garden's Virtual Herbarium. Available in <http://sweetgum. nybg.org/ih/>. Access on 18 Nov 2010.

Tippery, N.P.; Philbrick, C.T.; Bove, C.P. \& Les, D.H. 2011. Systematics and phylogeny of neotropical Podostemaceae. Systematic Botany 36: 105-118.

Tulasne, L.R. 1863. Podostemaceae. In: Martius, C.P.P. (ed.). Flora brasiliensis 4: 229-275, tab. 73-76.

Tur, N. M. 1975. Nueva espécie de Podostemaceae para Argentina Wettsteiniola apipensis. Boletín de la Sociedad Argentina de Botánica. 16: 320-324.

Tur, N.M. 1988. Podostemaceae. In: Burkhart, A. (ed.). Flora Ilustrada de Entre Rios. Vol 3. 
Tur, N.M. 1997. Taxonomy of Podostemaceae in Argentina. Aquatic Botany 57: 213-241.

Tur, N.M. 1999. Podostemaceae. In: Spichiger, R. \& Ramella, L. (eds.). Flora del Paraguay. Vol. 29.

Tur, N.M. 2003. Una Nueva especie de Marathrum (Podostemaceae) y nueva cita del genero para la Argentina. Hickenia 3: 1-35.

Weddell, H.A. 1873. Podostemaceae. In: DC. Prodromus Systematis Naturalis. Regni Vegetabilis. Vol. 17. Semptibus \& Masson, Medicinal Academinan, Paris. Pp. 39-89.

Walpers, G. 1852-1853. Podostemaceae. Annals Botanic Systematics 3: 431-444.
Warming, E. 1888. Familien Podostemaceae.Vidensk. Selsk. Skr. 6: 3-72 t. 16-27.

Van Royen, P. 1951. The Podostemaceae of the new world. Part I. Mededeelingen van het botanisch museum en herbarium van de rijks Universiteit te Utrecht. 107: 1-150.

Van Royen, P. 1953. The Podostemaceae of the new world. Part II. Acta Botanica Neerlandica 2: 1-20.

Van Royen, P. 1954. The Podostemaceae of the new world. Part. III. Acta Botanica Neerlandica 3: 215-263.

Van Royen, P. \& Reitz, Pe. R. 1971. Podostemaceae. Flora Ilustrada Catarinense. Herbário Barbosa Rodrigues. Pp. 1-36. 